\title{
Serum interferon levels and natural killer cell activity in patients with asbestosis
}

\author{
SANDANOBU KAGAMIMORI, MASAO WATANABE, MICHIO KUBOTA, \\ AKIRA OKADA, KUNIHIKO YOKOYAMA, KOICHI NOBUTOMO
}

From the Department of Community Medicine, Toyama Medical and Pharmaceutical University, Toyama City; the Department of Public Health, Kanazawa University School of Medicine, Kanazawa City; and the Kinki Chuoh Hospital, Sakai City, Japan

ABSTRACT Natural killer cell activity and serum interferon levels were measured in 30 patients with asbestosis. The chest radiographs showed type 1 changes (ILO pneumoconiosis classification) in nine, type 2 changes in 19, and type 3 changes in two. Thirty control subjects matched for age, sex, and smoking habit were also studied. Patients with asbestosis had significantly higher serum interferon levels than the controls. There was no significant difference in natural killer cell activity between patients with asbestosis and normal controls.

Cancers of the respiratory system have been shown to be significantly more common in patients with asbestosis than the general population. ${ }^{1}$ Pulmonary infection is common in asbestosis, though there is no information to indicate whether it is any more common than in other forms of lung fibrosis. Natural killer cells are thought to be responsible for the first defence mechanism against cancer cells and cells infected with virus. ${ }^{23}$ Furthermore, interferon has recently been found to have a regulatory role in natural killer cell activity, ${ }^{4}$ which appears to be enhanced by interferon. We undertook the present study to investigate serum interferon levels and natural killer cell activity in patients with asbestosis.

\section{Methods}

We studied 30 consecutive patients with asbestosis attending the pneumoconiosis clinic of Kinki Chuoh National Hospital. There were 15 men and 15 women (mean age 58 years, range 49-72) who were free of complications such as tuberculosis and carcinoma and were not taking steroids. There were nine cases of type 1, 19 of type 2, and two of type 3 as categorised according to the ILO pneumoconiosis classification. All were textile workers with a mean duration of 18 years (range 3-40 years) of exposure

Address for reprint requests: Dr S Kagamimori, Department of Community Medicine, Faculty of Medicine, Toyama Medical and Pharmaceutical University, Toyama City 930-01, Japan.

Accepted 12 July 1983 to chrysotile. Controls matched for age, sex, and smoking habit were selected from participants in a mass tuberculosis survey which covered over $90 \%$ of inhabitants in a community where there was no asbestos related industry. Controls had neither tuberculosis nor a history of occupational exposure to asbestos.

Mononuclear cells separated from heparinised peripheral blood on a Ficoll-Conray gradient (about 200000 cells) were incubated in triplicate for six hours with $10000 \mathrm{~K} 562$ target cells labelled with chromium-51 $\left({ }^{51} \mathrm{Cr}\right)$. The percentage specific ${ }^{51} \mathrm{Cr}$ release was used as a measure of natural killer cell activity. This was defined by the following formula: [(E-S)/(M-S)] $\times 100$, where $E$ is the experimental, $S$ the spontaneous, and $\mathrm{M}$ the maximum ${ }^{51} \mathrm{Cr}$ release. Antiviral titres of human serum interferon were measured by inhibition of the cytopathic effect of vesicular stomatitis virus on a monolayer of fetal lung cells. Antiviral units were expressed as the reciprocal of the highest dilution inhibiting $50 \%$ of the cytopathic effect, and were adjusted to reference U of the National Institutes of Health (NIH) human reference interferon (G-028-501-568).

\section{Results}

Patients with asbestosis showed higher serum interferon levels than the control subjects $(p<$ 0.001 , Wilcoxon rank sum test). Figure 1 shows that serum interferon levels of $20 \mathrm{U} / \mathrm{ml}$ or more were more frequent in patients than in controls and the 


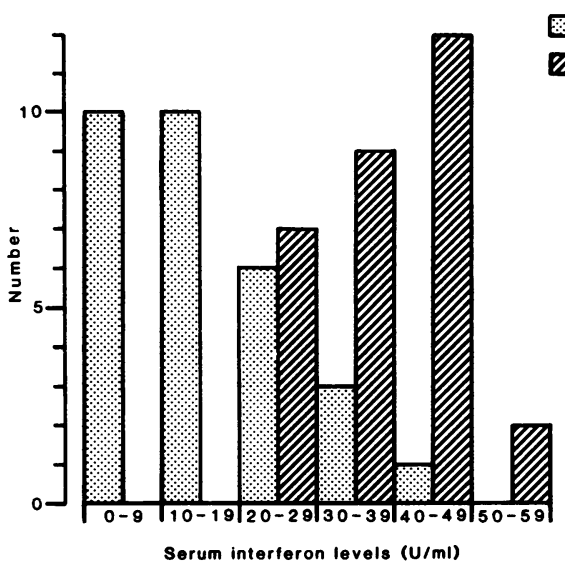

Fig 1 Distribution of serum interferon levels in controls and patients with asbestosis.

difference was significant $(p<0.01$, Fisher's direct probability test). These antiviral titres were resistant to treatment with IN hydrochloric acid $(\mathrm{pH} 2)$ and were abolished by antihuman interferon $\alpha$ (NIH research reference reagent G-026-502-568). Natural killer cell activity in the patients was slightly lower than in the controls, but the difference was not significant (Wilcoxon rank sum test). The correlation coefficient between natural killer cell activity and serum interferon levels was significant in patients but not in controls (fig 2).

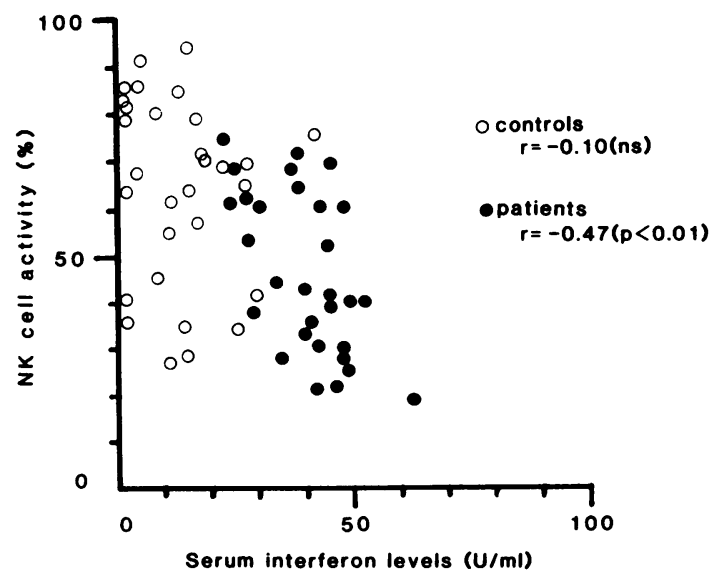

Fig 2 Serum interferon levels and natural killer cell activity in controls and patients with asbestosis.

\section{Discussion}

Although asbestos fibres have been shown to depress viral interferon production in vitro, ${ }^{5}$ our patients showed higher serum interferon levels than controls. Asbestosis seems to resemble autoimmune diseases with respect to the interferon-natural killer cell system, since increased serum interferon levels and depressed natural killer cell activity have been found in systemic lupus erythematosus ${ }^{67}$ and rheumatoid arthritis. ${ }^{68} \mathrm{~A}$ further example of an inverse correlation between interferon and natural killer cell activity has been reported in cases of multiple warts, ${ }^{9}$ in which natural killer cell activity appears to be depressed by interferon. By contrast, increased natural killer cell activity and decreased interferon production have been found in atopic dermatitis. ${ }^{10}$ The next step will be to investigate the proportion of natural killer cells in peripheral blood mononuclear cells and their sensitivity to exogenous interferon. These findings may provide an indicator of susceptibility to malignancy for patients with asbestosis.

\section{References}

1 Gilson JC. Asbestos cancer: past and future hazards Proc R Soc Med 1973;66:395-403.

${ }^{2}$ Kiessling R, Haller $O$. Natural killer cells in the mouse: an alternative immune surveillance mechanism? Contemp Topics Immunobiol 1978;8:171-201.

${ }^{3}$ Santoli D, Koprowski H. Mechanisms of activation of human natural killer cells against tumor and virusinfected cells. Immunol Rev 1979;44:125-63.

${ }^{4}$ Targan S, Dorey F. Dual mechanism of interferon augmentation of natural killer cytotoxicity (NKCC). Ann NY Acad Sci 1980;350:121-9.

${ }^{5}$ Hahon N, Eckert HL. Depression of viral interferon induction in cell monolayers by asbestos fibers. Environ Res 1976;11:52-65.

${ }^{6}$ Hooks JJ, Moutsopoulos HM, Geis SA, Stahl NI, Decker JL, Notkins AL. Immune interferon in the circulation of patients with autoimmune disease. $N$ Engl J Med 1979;301:5-8.

${ }^{7}$ Oshimi K, Sumiya M, Gonda N, Kano S, Takaku F. I Natural killer cell activity in systemic lupus erythematosus. Lancet 1979;ii:1023.

${ }^{8}$ Itoh K, Saitoh F, Kumagai K, Kosaka S. Depressed $\widetilde{N}$ natural killer cell activity in rheumatoid arthritis and $\mathrm{N}$ its in vitro augmentation with interferon and $N$ - 요 (2-carboxyphenyl)-4-chloroantranilic acid disodium $\omega$ salt (CCA), an anti-arthritis agent. Ryumachi 1981 ;21, suppl: $69-74$.

${ }^{9}$ Ho M, White LT, Haverkos HW, Breining MC, Pazin GJ, Armstrong JA. Depression of natural killer cell $\mathbb{E}$ activity by interferon. $J$ Infect Dis $1981 ; 114: 605$.

${ }^{10}$ Strannegård IL, Strannegård $O$. Natural killer cells and interferon production in atopic dermatitis. Acta Derm Venereol 1980;92, suppl: 48-51. 